\title{
Foreign direct investment and spillovers through workers' mobility
}

\author{
Andrea Fosfuri ${ }^{\mathrm{a}, \mathrm{b}, *}$, Massimo Motta ${ }^{\mathrm{c}, \mathrm{d}}$, Thomas Rønde ${ }^{\mathrm{e}}$ \\ ${ }^{a}$ Universidad Carlos III de Madrid, Calle Madrid 126, 28903 Getafe, Madrid, Spain \\ ${ }^{\mathrm{b}}$ CEPR, London, UK \\ ${ }^{\mathrm{c}}$ European University Institute, Florence, Italy \\ ${ }^{\mathrm{d} U n i v e r s i t a t ~ P o m p e u ~ F a b r a, ~ B a r c e l o n a, ~ S p a i n ~}$ \\ ${ }^{\mathrm{e}}$ University of Mannheim, Mannheim, Germany
}

\begin{abstract}
We analyze a model where a multinational fir can use a superior technology in a foreign subsidiary only after training a local worker. Technological spillovers from foreign direct investment arise when this worker is later hired by a local firm Pecuniary spillovers arise when the foreign affiliat pays the trained worker a higher wage to prevent her from moving to a local competitor. We study conditions under which these spillovers occur. We also show that the multinational fir might fin it optimal to export instead of investing abroad to avoid dissipation of its intangible assets or the payment of a higher wage to the trained worker.
\end{abstract}

Keywords: Multinational corporations; Externalities; Spillovers; Training; Labor mobility

JEL classificatio : F23; J63; O12

\section{Introduction}

The last two decades have witnessed an important change in the attitude of host countries towards multinational enterprises (MNEs). Most countries have removed

\footnotetext{
*Corresponding author. Universidad Carlos III de Madrid, Calle Madrid 126, 28903 Getafe, Madrid, Spain. Tel.: +34-91-624-9351; fax: +34-91-624-9608.

E-mail address: fosfuri@emp.uc3m.es (A. Fosfuri).
} 
their barriers to foreign direct investment (FDI) and have actively encouraged investment by foreign firms Advocates of these policies claim that MNEs generate spillovers which benefi the host economy. Such spillovers may take several forms. ${ }^{1}$

First, there may exist backward and forward linkages between foreign affiliate and local firm (Lall, 1980; Rodriguez-Clare, 1996). Second, foreign affiliate may increase local firms productivity through "demonstration effects". For example, domestic competitors might successfully imitate technological innovations introduced by MNEs (Mansfiel and Romeo, 1980; Blömstrom, 1986). Third, spillovers arise when subsidiaries of foreign firm train local employees who later join local firm or set up their own companies, bringing with them all (or part of) the technological, marketing, and managerial knowledge that they have acquired.

In this paper, we focus on this last form of spillovers, and we present a model in which technological spillovers arise due to the mobility of workers who have been trained by MNEs. Our main purpose is to study the conditions under which such spillovers occur.

The fact that MNEs undertake substantial efforts in the education of local workers has been documented in many instances (e.g., ILO, 1981; Lindsey, 1986), and empirical research seems to indicate that MNEs offer more training to technical workers and managers than do local firm (Chen, 1983; Gerschenberg, 1987). In early stages, affiliate rely more intensively on expatriates, but subsequently they tend to replace them with (cheaper) local workers who have been properly trained in the meanwhile (UNLTC, 1993).

However, evidence on spillovers due to workers' mobility is scarce and far from conclusive. ${ }^{2}$ An early study by Behrman and Wallender (1976) shows that, while labor mobility is important in certain circumstances, it is minimal in others. Gerschenberg (1987) analyzes MNEs' activity in Kenya. He concludes that mobility is lower for managers employed by MNEs than for those employed by local firms In a study of the Taiwanese economy, Pack (1993) find that labor mobility from MNEs to local firm is important and that often trained managers leave MNEs to run their own businesses. Aitken et al. (1997) study the effect of inward FDI on the wages of the local workforce in three different host countries. In Mexico and Venezuela, inward FDI increases the wages of the workers in MNE affiliates but has no effect on the wages of local firms workers. In the US, inward FDI results in higher wages both in MNE affiliate and in local firms Indirectly, this might show the existence of technological spillovers through labor mobility in the US, whereas in Mexico and Venezuela such labor mobility might be inhibited by either the higher wages paid by the MNEs or a larger technology gap.

Our paper provides a formalization which is consistent with these findings We build a model where a MNE trains a local worker to run its subsidiary. Later, the

\footnotetext{
${ }^{1}$ See Blömstrom and Kokko (1998) for an extensive review of FDI spillovers.

${ }^{2}$ See also Blömstrom and Kokko (1998).
} 
MNE and a local fir compete for the services of the trained worker. As a result, the MNE manages to keep the worker only if it offers better conditions than the local firm Spillovers from foreign direct investment can take two forms. Technological spillovers arise when the trained worker is hired by the local firm Pecuniary spillovers arise when the MNE pays the worker a higher wage to prevent her from moving to the local competitor.

We fin that the so-called "joint profit' effect (or "efficiency' effect) plays an important role in determining which type of spillovers arises. We show that technological spillovers do not occur if the joint profi of the MNE and the local fir is highest when the MNE can use the technology as a monopolist. This result is similar to that obtained in the literature on the persistence of monopolies (see Tirole, 1988). The empirical implication is that one should expect higher labor mobility and more spillovers (both technological and pecuniary) when the local fir can use the technology in activities that do not compete fiercel with the MNE. This occurs, for example, when the local fir can operate in markets for products which are unrelated or complementary to the MNE's products. Unfortunately, we are aware of no empirical studies which try to link the existence of spillovers with the sectors of activity of multinational and local firms

We also fin that a low level of "absorptive capability" by the local firm which might be due to technological backwardness, reduces the potential for FDI generating spillovers. The empirical evidence seems to confir that spillovers increase with the degree of absorptive capability of host country firm (see, for instance, Kokko, 1994; Borensztein et al., 1998).

Further, the mobility of the trained workers is higher the more general is the on-the-job training given by the MNE, which is consistent with the labor economics literature (e.g., Becker, 1964). Our addition to this literature is to show that it is not only the nature of the training (general versus specifi ), but also the degree of product market competition which affects labor mobility.

Finally, the MNE might anticipate that investing abroad would lead either to technological spillovers or to higher wages and choose to export instead. Anecdotal evidence confirm that this may sometimes be the reason why MNEs export. An illustrative example is drawn from the history of the chemical sector (Kudo, 1993). After World War I, the leading German chemical company, IG Farben, decided to increase its activity in the growing Japanese market, whose chemical industry was still at an infant stage. IG Farben resorted to exporting and avoided FDI (and licensing) as much as possible in order to minimize the diffusion of technology to competitors.

Other game theoretical models have analyzed spillovers to foreign markets, although from different perspectives. In Ethier and Markusen (1996), technological spillovers arise as a result of a double moral hazard problem. A foreign fir endowed with a superior technology might renege on an exclusive contract with a local licensee by transferring technology to other local firms whereas the licensee might "cheat" by introducing a marginal improvement in the technology. Fosfuri 
and Motta (1999) and Siotis (1999) analyze the decision between exporting and FDI, but they simply assume that when two firm locate in the same region a proportion of their know-how spills over to each other. This "black box" type of spillovers is quite familiar in the R\&D literature (e.g., d'Aspremont and Jacquemin, 1988).

The rest of this paper is organized as follows. Section 2 presents the model, analyzes the equilibrium outcomes and discusses the results obtained. Section 3 concludes the paper.

\section{The model}

A multinational enterprise (MNE) has some payoff relevant information which can be thought of as a new technology, a new production process, a new managerial technique, or a new organizational form. We will call this information "technology". The technology has been accumulated prior to the game and it is exogenously given in our model. It has not yet been introduced to the foreign market on which we focus.

The MNE can either serve the foreign market through exports or establish a local subsidiary (i.e. do FDI). We disregard uninteresting cases where selling in the foreign market is not profitable FDI requires the fir to transfer its technology to the subsidiary. We assume that such a transfer is successful only if a local worker is well acquainted with the technology. The relevant technology can only be transmitted through oral communication or on-the-job training.

Apart from the MNE, there also exists a local fir $l$ which could sell the product if it knew how the technology worked. We exclude the possibility of licensing agreements by assuming that the costs of contracting upon this knowledge-based asset are large enough.

The basic features of the game are described in Fig. 1.

At time $T=0$, the MNE decides whether to export or to do FDI. When exporting, the fir will make use of production facilities and trained workers located in the home country. When investing in the host market, the MNE will have to incur a fixe cost $G$, which includes all the expenses associated with operating in an unfamiliar foreign environment. The local fir does not have to incur this cost since it is already familiar with the local market.

In addition, if FDI is chosen, the MNE sends a staff of supervisors to the affiliat to train a local worker. After completion of the training, they return to headquarters. ${ }^{3}$ The total cost of training the worker is $F$, which we set equal to zero for simplicity.

The worker who receives training is hired from a pool of identical untrained

\footnotetext{
${ }^{3}$ Alternatively, a local worker is given training at the parent company.

${ }^{4}$ Qualitative results do not change with $F>0$; see Fosfuri et al. (1998).
} 

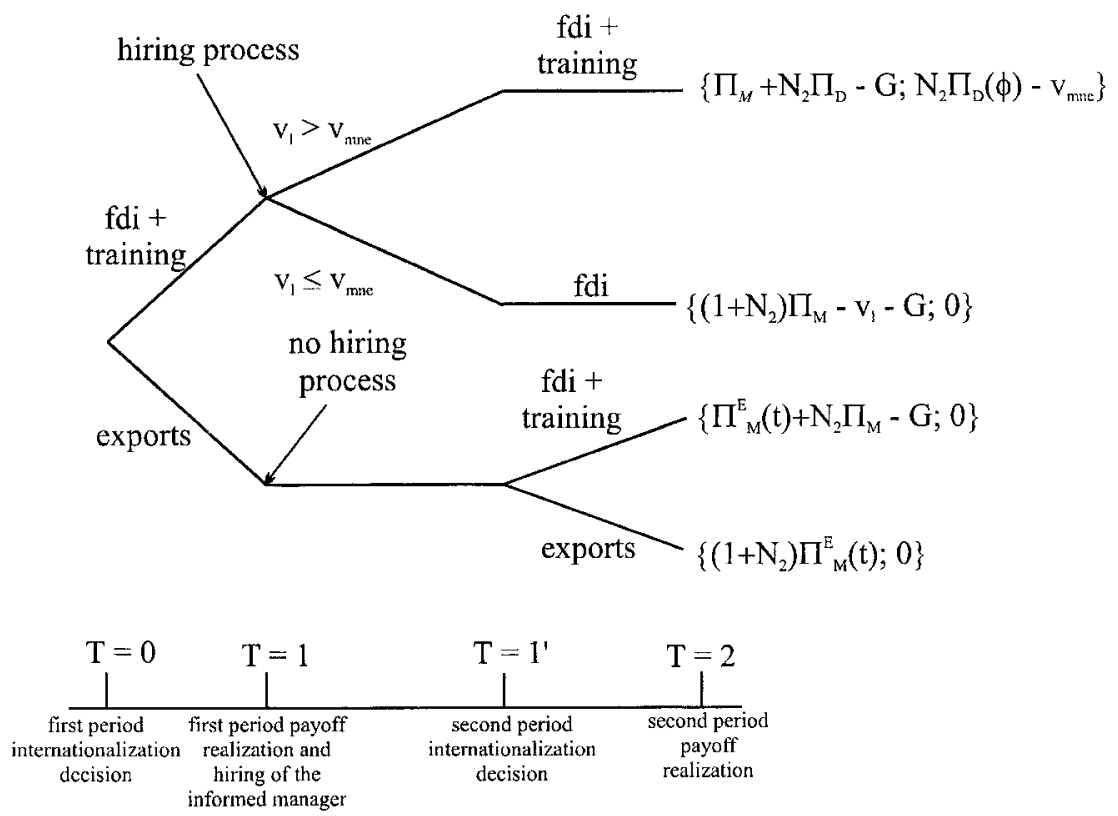

Notes:

1. In brackets are respectively the payoffs of the MNE and of the local firm.

2. $v_{1}=N_{2} \Pi_{D}(\phi)-k ; v_{m n c}=N_{2}\left(\Pi_{M}-\Pi_{\mathrm{D}}(\phi)\right)$.

Fig. 1. The game tree.

workers. She is paid the subsistence wage $\bar{w}$ which is normalized to zero. We assume that the MNE can only write a one-period contract with the worker. We also assume that the worker is wealth-constrained and that she cannot borrow on the financia market, so that her first-perio wage must be non-negative. We discuss these assumptions in more detail at the end of this section.

After having received proper training, the local worker (henceforth we shall refer to her as the "trained" worker) has acquired all the necessary expertise, technology and information to produce the good. At period $T=1$, production takes place, the good is sold and first-perio profit are realized. The MNE is a monopolist in the market in the firs period, since the local fir has no access to its technology. $N_{1}$ is the size of the market in period 1 , as measured by the number of consumers. The MNE's profi is $N_{1} \Pi_{\mathrm{M}}^{\mathrm{E}}(t)$ if it exports, where $t$ is an export cost (tariff, transportation cost or wage differential). If the MNE does FDI, its profi is $N_{1} \Pi_{\mathrm{M}}$ (gross of set up costs), with $\Pi_{\mathrm{M}}>\Pi_{\mathrm{M}}^{\mathrm{E}}(t)$. We set $N_{1}=1$ without loss of generality.

After production takes place, fir $l$ realizes that it could also gain access to the 
technology by hiring the trained worker. The MNE would like to retain her to avoid the dissipation of the rents associated with her technology.

We model competition for the worker in the following way. Each fir simultaneously and independently makes a take-it-or-leave-it offer to the trained worker. The fir who offers more hires the worker and pays the wage it has offered. Put differently, the hiring process works like a first-pric auction. If both firm offer the same wage we assume that the fir whose valuation of the worker is highest hires her (this assumption is made to guarantee equilibrium in pure strategies). We assume that firm have symmetric information about the value of the trained worker. ${ }^{5}$ Also, note that we are assuming away the possibility that the local fir might hire workers from the home country of the MNE. Therefore, no spillovers can occur when the MNE chooses to export. ${ }^{6}$ This amounts to saying that spillovers are localized (e.g., Audretsch and Feldman, 1996).

We shall focus on the equilibrium in which the fir whose valuation of the worker is highest hires her by offering exactly the rival's valuation. ${ }^{7}$ This implies that the trained worker will appropriate some of the rents created by the technology.

Each firm' valuation of the worker depends on its outside options. We assume that fir $l$ can only acquire the technology by hiring the worker (imitation is ruled out in our model). Hence, the local fir will make zero profit in the second period if it does not succeed in attracting the worker. If the MNE loses the trained worker, it will redeploy the staff from the headquarters to train another local worker.

After the MNE has decided between exports and FDI, production takes place and the second-period payoffs are realized. For simplicity, we assume a discount factor of 1 . We denote by $N_{2}$ the second-period market size. If the MNE keeps the trained worker, its second period payoff is given by $N_{2} \Pi_{\mathrm{M}}$ (gross of the wage paid to the worker), while it is $N_{2} \Pi_{\mathrm{M}}^{\mathrm{E}}(t)$ if it exports.

For expositional reasons, we focus firs on the case where the MNE does not export in the last period of the game. This is the case if the following holds:

\section{Assumption A1.}

$$
N_{2}\left(\Pi_{\mathrm{M}}-\Pi_{\mathrm{M}}^{\mathrm{E}}(t)\right) \geq G
$$

\footnotetext{
${ }^{5}$ In Fosfuri et al. (1998) we deal with the case of asymmetric information about the value of the trained worker, and show that our results are not sensitive to this change.

${ }^{6}$ It seems reasonable to assume that it is more difficul for the local fir to identify trained workers if they are in another country, and/or to attract such workers from abroad if identified

${ }^{7}$ We disregard equilibria where both firm offer a wage between the lowest and the highest valuation of the worker (and where the fir with the highest valuation hires her), since in these equilibria the fir with the lowest valuation is playing a weakly dominated strategy.
} 
Below we shall discuss briefl the case where A1 is not satisfied

If the local fir hires the trained worker and enters the market, both firm earn gross profi $N_{2} \Pi_{\mathrm{D}}(\phi)$ (the label D standing for "duopoly"). The parameter $\phi \in[0,1]$ is an inverse measure of the degree of competition in the industry. We assume that $\Pi_{\mathrm{D}}(\phi)$ is differentiable and strictly increasing in $\phi$ with $\Pi_{\mathrm{D}}(0)=0$ and $\Pi_{\mathrm{D}}(1)=\Pi_{\mathrm{M}}$. The degree of competition is affected by variables such as product differentiation, the mode of competition (e.g., price versus quantity competition), and competition laws and their enforcement in the local country. For instance, with homogenous products and price competition $\phi=0$, while with independent markets $\phi=1$.

We also assume that the local fir has to pay a fixe cost $k \geq 0$ to benefi from the technology brought in by the trained worker. The parameter $k$ measures the absorptive capability of the local fir and the transferability of the technology received by the worker. If she receives general training, such as organizational, managerial or marketing skills that can be costlessly used in other firm (and possibly other industries), $k$ will be very low. If instead the worker has received training in firm-specif technology, the local fir will fin it more costly to adapt this technology to its own production process, and $k$ will be high.

We take $\phi$ and $k$ to be exogenous and do not specify any functional relationship between them.

We look for the sub-game perfect equilibrium in pure strategies of the game just described. We solve the model by backward induction.

\subsection{Equilibrium solutions}

As a firs step, we determine the outcome of the bidding for the trained worker. The local firm' valuation of the worker is $v_{l}=N_{2} \Pi_{\mathrm{D}}(\phi)-k$. The MNE will earn monopoly profi if it keeps the worker, and duopoly profi if it loses her to the local competitor. Therefore, the MNE's valuation of the worker is $v_{\mathrm{mne}}=N_{2}\left(\Pi_{\mathrm{M}}-\right.$ $\left.\Pi_{\mathrm{D}}(\phi)\right)$.

Two situations are possible: either $v_{\text {mne }} \geq v_{l}$, and the MNE keeps the worker by

\footnotetext{
${ }^{8}$ The distinction between general and specifi on-the-job training is due to Becker (1964). In Becker, there is specifi (general) training when workers' productivity is lower (equal) in other firm than in the fir which provides the training. We model this by means of a fixe cost, but the effect is the same, as $k$ reduces the net payoff from hiring a worker trained elsewhere.

${ }^{9}$ Parameters $k$ and $\phi$ might be related, but their relationship is not a priori obvious, as it might depend on the nature of the technology being transferred. For instance, one might expect that the technology received by the worker can be passed on to a rival fir more easily when the products are similar. However, if the worker has received general training, this technology could just as easily be transferred to firm which sell independent or complementary products as to firm which sell close substitutes. Further, it might be more difficul to transfer knowledge to a fir which sells similar products but has a different organizational or production structure than to a fir which sells less related products but has a similar structure.
} 
paying her $w=N_{2} \Pi_{\mathrm{D}}(\phi)-k$; or $v_{\text {mne }}<v_{l}$, and the local fir hires the trained worker by paying her $w=N_{2}\left(\Pi_{\mathrm{M}}-\Pi_{\mathrm{D}}(\phi)\right)$. In the firs case, the MNE pays the local worker more than the wage in the pool, and the local economy enjoys a pecuniary spillover. In the second case, a technological spillover occurs, since the local fir manages to appropriate the MNE's technology. ${ }^{10}$ The following lemma summarizes the outcome of the hiring process.

Lemma 1. Technological spillovers never arise if:

$$
N_{2}\left(\Pi_{M}-2 \Pi_{D}(\phi)\right)+k \geq 0 .
$$

Proof. Spillovers do not occur if $v_{\text {mne }} \geq v_{l}$. After substituting, this inequality can be written as $N_{2}\left(\Pi_{\mathrm{M}}-\Pi_{\mathrm{D}}(\phi)\right) \geq N_{2} \Pi_{\mathrm{D}}(\phi)-k$. Rearranging, this gives condition (1).

To better interpret this result, let us introduce the following definition

Definition The "joint profit' effect holds (does not hold) if the sum of the gross profit of two duopolists is smaller (larger) than or equal to the gross profi of a monopolist.

The "joint profit' effect implies that $\Pi_{\mathrm{M}} \geq 2 \Pi_{\mathrm{D}}(\phi)$. This is sufficien to ensure that condition (1) holds and that the local fir will not hire the trained worker. This result is reminiscent of the industrial organization literature which studies persistence of leadership over time. Indeed, the "joint profit' effect, also called the "efficiency' effect, has been identifie as the main condition under which a monopolist manages to keep out potential entrants (e.g., Budd et al., 1993; Tirole, 1988).

The "joint profit' effect holds when the duopolists are competing fiercel enough. Condition (1) can also be written in terms of the "competition" parameter as $\phi \leq \phi_{1} \equiv \Pi_{\mathrm{D}}^{-1}\left[\left(\Pi_{\mathrm{M}} / 2\right)+\left(k / 2 N_{2}\right)\right]$. This curve is illustrated in Fig. 2. It is positively sloped in $(k, \phi)$ as $\mathrm{d} \phi / \mathrm{d} k=1 /\left[2 N_{2}\left(\mathrm{~d} \Pi_{\mathrm{D}}(\phi) / \mathrm{d} \phi\right)\right]>0$.

We can now move on to the equilibrium solution of the whole game, which is given by the following:

\section{Proposition 1.}

(i) FDI and technological spillovers. The MNE invests in the firs period and there exist technological spillovers if condition (1) does not hold and:

$$
\Pi_{M}-\Pi_{M}^{E}(t) \geq N_{2}\left(\Pi_{M}-\Pi_{D}(\phi)\right) ;
$$

\footnotetext{
${ }^{10}$ Notice that, in both cases, the worker benefit from a pecuniary spillover which puts her two-period income above that earned by the workers in the pool.
} 


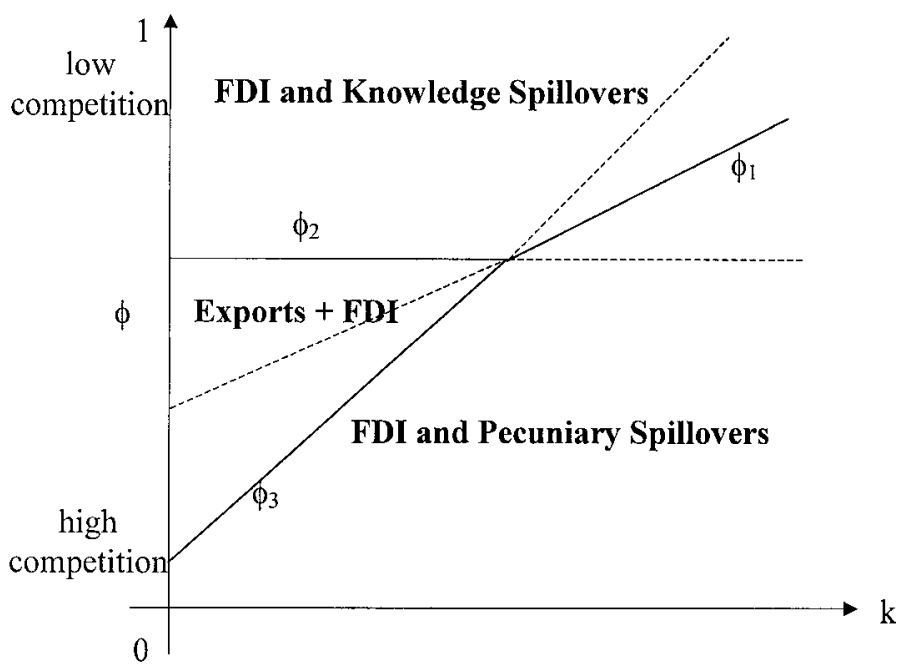

Fig. 2. The equilibrium outcome.

(ii) FDI and pecuniary spillovers. The MNE invests in the firs period but technological spillovers do not occur if condition (1) holds and:

$$
\Pi_{M}-\Pi_{M}^{E}(t) \geq N_{2} \Pi_{D}(\phi)-k
$$

(iii) Exports. The MNE exports in the firs period, and no spillovers arise, otherwise.

Proof. (i) If condition (1) does not hold, technological spillovers would occur if the MNE invested in the firs period, by Lemma 1. Therefore, the MNE's decision is between investing (and later losing the trained worker) and exporting in order to avoid competition in the second period (when the MNE will invest). Investing is preferred to exporting if: $\Pi_{\mathrm{M}}-G+N_{2} \Pi_{\mathrm{D}}(\phi) \geq \Pi_{\mathrm{M}}^{\mathrm{E}}(t)+N_{2} \Pi_{\mathrm{M}}-G$, which rearranged gives condition (2).

(ii) If condition (1) holds, technological spillovers do not arise in case of FDI in the firs period. Investing is preferred to exports if: $\Pi_{\mathrm{M}}-G+N_{2} \Pi_{\mathrm{M}}-$ $\left(N_{2} \Pi_{\mathrm{D}}(\phi)-k\right) \geq \Pi_{\mathrm{M}}^{\mathrm{E}}(t)+N_{2} \Pi_{\mathrm{M}}-G$, where $N_{2} \Pi_{\mathrm{D}}(\phi)-k$ is the wage paid to the trained worker to prevent her from moving to the local fir in the second period. Rewritten, this inequality gives condition (3).

(iii) If neither condition (1) nor condition (2) hold, the MNE prefers to export to prevent technological spillovers from occurring. If condition (1) holds but condition (3) does not, the MNE prefers to export to avoid pecuniary spillovers. 
The equilibrium outcomes are illustrated in Fig. 2. The three loci $\phi_{1}, \phi_{2}, \phi_{3}$ correspond to conditions (1), (2), (3) in Proposition 1. Locus $\phi_{1}$ has already been discussed above. Condition (2) can be written as $\phi \geq \phi_{2} \equiv \Pi_{\mathrm{D}}^{-1}\left\{\left(\Pi_{\mathrm{M}}^{\mathrm{E}}(t) / N_{2}\right)+\right.$ $\left.\Pi_{\mathrm{M}}\left[1-\left(1 / N_{2}\right)\right]\right\}$, which is independent of $k$. Condition (3) can be written as: $\phi \leq \phi_{3} \equiv \Pi_{\mathrm{D}}^{-1}\left[\left(\Pi_{\mathrm{M}}-\Pi_{\mathrm{M}}^{\mathrm{E}}(t) / N_{2}\right)+\left(k / N_{2}\right)\right]$, which is positively sloped as $\mathrm{d} \phi_{3} /$ $\mathrm{d} k=1 / N_{2}\left(\mathrm{~d} \Pi_{\mathrm{D}}(\phi) / \mathrm{d} \phi\right)>0$. Note also that we do not need to make assumptions on the sign of $\mathrm{d}^{2} \Pi_{\mathrm{D}}(\phi) / \mathrm{d} \phi^{2}$, which implies that curves $\phi_{1}$ and $\phi_{3}$ can be convex, concave or linear (in the graph we arbitrarily chose to draw them as being linear, but this obviously does not affect the results we obtain). When the region with exports exists, i.e. $\left[\Pi_{\mathrm{M}}-\Pi_{\mathrm{M}}^{\mathrm{E}}(t)\right] / N_{2}<\Pi_{\mathrm{M}} / 2$, the curves $\phi_{1}, \phi_{2}, \phi_{3}$ intersect at the same point.

Let us discuss the results obtained. First, notice that technological spillovers occur when market competition is low ( $\phi$ is high) and technology is easily transferable ( $k$ is low). The role played by each variable can be easily understood through the following thought experiments. Suppose that we are close to the origin, so that both $k$ and $\phi$ are low. This region is characterized by easily transferable technology but strong market competition. Strong competition implies that the local fir gets low profit from hiring the trained worker. The MNE would retain the worker by paying a small additional wage (pecuniary spillovers would arise) and there is no reason to export instead of investing. Now keep $k$ fixe but increase $\phi$. As $\phi$ rises, competition weakens and the bid made by the local fir increases. Accordingly, the second-period wage necessary to retain the worker increases with $\phi$. In the region $\phi_{1}>\phi>\phi_{3}$ it is cheaper for the MNE to export in the firs period than to do FDI and later pay the additional wage to the trained worker. For still higher values of $\phi\left(\phi_{2}>\phi>\phi_{1}\right)$, the local firm' profi in the case it hires the worker would be so high that it would outbid the MNE at the equilibrium. In this region, however, competition is still strong enough for the MNE to be hurt from losing its technology to a rival. Hence, the MNE exports in the firs period to avoid dissipation of its technology. Finally, if $\phi$ rises even further $\left(\phi>\phi_{2}\right)$, product market competition becomes so weak that the MNE's profi would not decrease much if the local fir hired the trained worker. As a result, at equilibrium the MNE prefers to invest in the firs period even though it anticipates that it will lose the worker in the following period.

A similar line of reasoning clarifie the role played by the parameter $k$ which measures the transferability of the technology. For any given degree of product market competition, an increase in $k$ will lower the payoff the local fir would obtain were it able to hire the trained worker. As a result, its bid will be lower and the MNE will fin it cheaper to retain its worker. Hence, for any given $\phi$ the region where the MNE invests in the firs period and pecuniary spillovers occur becomes larger.

Our results imply the following empirical predictions about the occurrence of technological spillovers. First, one should expect, other things being equal, such spillovers to occur when the multinational and the local fir are not direct 
competitors. This might mean that the local fir operates in another sector, produces a good which is vertically related to the MNE's production (either upstream or downstream), or sells its products in a different geographical area than the MNE. Of course, testing such a prediction would require very disaggregated data, which might explain why, to our knowledge, this analysis has not yet been undertaken. Nevertheless, Pack (1993) reports some anecdotal evidence about trained workers who leave MNEs to start their own businesses in activities which do not compete with the MNE's business.

Of course, the extent to which technological spillovers occur depends on the nature of the technology and how easily it can be transferred. It is well known since the work of Becker (1964) that the more specifi the on-the-job training (or the less easily transferable the technology) the lower the expected mobility of trained workers. This effect is captured by the aforementioned results: technological spillovers occur only if $k$ is low enough. But $k$ can also be interpreted as an inverse measure of the absorptive capability of the local fir (Cohen and Levinthal, 1989). Then, a high $k-$ a low level of absorptive capability -reduces the region in which technological spillovers occur. The prediction of our model is thus consistent with the empirical findin that low levels of absorptive capability of local firm are associated with reduced benefit from FDI (e.g., Kokko, 1994; Borensztein et al., 1998). This might also have a cross-country implication, as one would expect higher labor mobility and more technological spillovers in host countries that are technologically advanced and have a highly skilled labor force. ${ }^{11}$

Finally, a more speculative interpretation of $k$ is as a measure of the protection of intellectual property in the host country. Under the laws of trade secrets, the worker is not allowed to disclose the MNE's valuable technology to the local firm Thus, $k$ could be thought of as the expected fin the local fir has to pay if the worker discloses the technology, or the expected cost if a non-compete covenant is enforced. ${ }^{12}$ In this perspective, Lee and Mansfiel (1996) show that better general protection of intellectual property increases the probability of multinational firm investing in the country.

The literature on training has emphasized that one of the effects of "poaching" workers who have been trained elsewhere is to reduce the benefi of training itself, which in turn leads to underinvestment in training. In our model, poaching might lead the fir to export in the firs period. The effect is similar, as the export choice involves no training of local workers. Acemoglu and Pischke (1998) point out that,

\footnotetext{
${ }^{11}$ The fact that Aitken et al. (1997) fin some (indirect) evidence of labor turnover in the US but not in Mexico and Venezuela might be consistent with this implication of our analysis. See also Borensztein et al. (1998).

${ }^{12} \mathrm{~A}$ non-compete covenant specifie the period of time (and the geographic area) for which the employee cannot work for a competitor after leaving the fir (see, e.g., Budden, 1996). If a non-compete covenant is enforced, the local fir incurs a loss since it cannot acquire the technology immediately after the worker leaves the MNE.
} 
in countries where the institutional structure makes poaching more difficul (Germany, where wages for similar workers are fixe across firm and across regions, is a case in point), training levels will be higher than in markets where poaching raids are not restricted. Here we have a result of the same flavor as restrictions on labor mobility can be seen as an increase in the transferability cost $k$.

\subsection{Comparative statics}

Figs. 3(i) and 3(ii) illustrate some simple comparative statics with respect to $t$ and $N_{2}$. In Fig. 3(i), we show the effect of an increase in transportation costs or tariffs, $t$. Since the export strategy becomes more costly, the region where FDI occurs at equilibrium is larger ( $\phi_{2}$ shifts downwards, and $\phi_{3}$ shifts to the left). This is due to the traditional "tariff-jumping" motivation for FDI and it is a well-known outcome (see Motta, 1992). Moreover, the downward shift of $\phi_{2}$ increases the size of the region with technological spillovers. This implies that tariffs and similar policy instruments might be used to attract new technology into the country. According to Siotis (1999), this is precisely the policy followed by the European Commission to appropriate leading Japanese technology in the parts and components consumer electronics industry. He reports that Japanese firm had used only exports and avoided licensing agreements and FDI in the EU as a way to preserve their technological edge. Since changes in quotas and tariffs were ruled out by the EU commitment in the Uruguay Round negotiations, the European Commission threatened to use other measures such as antidumping duties and safeguard clauses to discourage Japanese exports, promote investments, and create technological spillovers.

However, the result that an increase in export costs $t$ might lead to FDI and technological spillovers (whereas no spillovers would have arisen in the absence of government intervention) is conditional on the change in the equilibrium outcome, and entails an important discontinuity. ${ }^{13}$ If the government were not able to predict the outcome of the game with sufficien precision, it might choose a tariff rate which is not high enough for the MNE to switch to FDI. The effect of the tariff might then be detrimental, due to lower consumer surplus. Therefore, strong informational requirements are needed to ensure that a government can intervene to improve welfare.

Fig. 3(ii) illustrates how the equilibrium outcome changes when the secondperiod market size expands. At equilibrium, a higher value of $N_{2}$ enlarges the region where exports occur, but its overall effect on technological spillovers is ambiguous. To see why, note that an increase in $N_{2}$ produces the following effects.

\footnotetext{
${ }^{13}$ See Horstmann and Markusen (1992) for similar discontinuities in equilibria in a model that analyzes the choice between FDI and exports.
} 

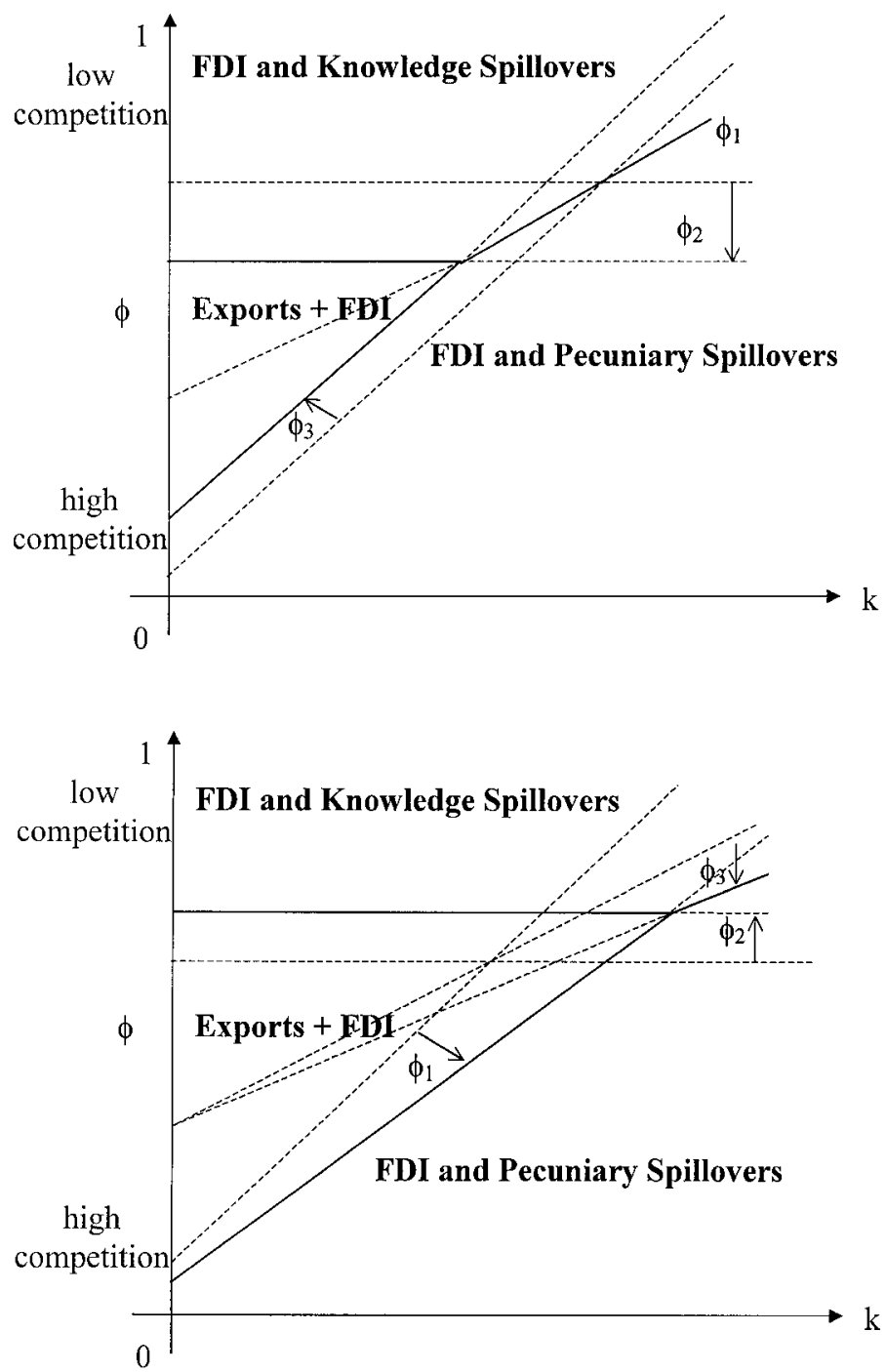

Fig. 3. (i) The effect of an increase in $t$; (ii) the effect of an increase in $N_{2}$.

First, the fixe cost $k$ becomes less important relative to profit (which increase in $\mathrm{N}_{2}$ ), implying that the local fir offers a higher wage to the trained worker. Hence, technological spillovers occur for a larger subset of the parameter space given that the MNE invests in the firs period (the slope of $\phi_{1}$ decreases). Furthermore, in order to keep the worker the MNE has to pay a higher wage. This makes FDI less 
attractive and the MNE chooses to export even if technological spillovers would not have resulted (the curve $\phi_{3}$ shifts downwards and becomes flatte ). Finally, a larger $N_{2}$ implies that competition in the second period would dissipate a larger (absolute) value of duopoly profits so that the MNE has a stronger incentive to choose costly exports in the firs period ( $\phi_{2}$ moves up). This reduces the possibility of technological spillovers.

The analysis leads to the somewhat unexpected implication that exports might be chosen initially in fast growing markets to avoid technology diffusion. There exists some evidence that exports are chosen in the early periods of foreign activity. Admittedly, though, there are probably other stories which explain this evolution better, such as the desire to know a market well before committing important resources (Horstmann and Markusen, 1996). Nevertheless, our results suggest that the attempt to keep technological potential intact might also play a role in certain circumstances.

\subsection{Relaxing Assumption A1}

A discussion of the effect of market size growth would be incomplete without reminding the reader that we have so far analyzed equilibrium outcomes under A1, which assumes that exports are never profitabl in the second period. It would be easy to show that relaxing this assumption ${ }^{14}$ would not modify our conclusions much with respect to the roles played by the parameters $k, \phi$ and $t$.

However, the effect of an increase in $N_{2}$ is worth mentioning because some non-monotonicities ${ }^{15}$ in the export versus FDI decision might appear. This effect is illustrated in Fig. 4. ${ }^{16}$ For simplicity, we draw the equilibrium outcome in the $\left(N_{2}, \phi\right)$ plane, for the case of $G-\left(\Pi_{\mathrm{M}}-\Pi_{\mathrm{M}}^{\mathrm{E}}(t)\right)>k$. Along the dashed horizontal lines in the figur (that is, for given degrees of product competition), the decisions about involvement in the foreign market can have a reversal as the second-period market grows. When market size is small, the optimal strategy for the MNE is to export in both periods. At intermediate levels of $N_{2}$, the MNE find it optimal to invest in the firs period because of the usual market size effect (as size grows, the fixe cost of FDI decreases relative to profit). But for large second-period markets, the relative importance of second-period profit is very high, and the MNE exports to avoid (technological or pecuniary) spillovers.

\footnotetext{
${ }^{14}$ However, in order for the analysis to have some interest we do assume that the MNE would always do FDI in the absence of spillovers, i.e. $\left(1+N_{2}\right)\left(\Pi_{\mathrm{M}}-\Pi_{\mathrm{M}}^{\mathrm{E}}(t)\right)>0$.

${ }^{15} \mathrm{We}$ are grateful to a referee for pointing out this possibility.

${ }^{16}$ Note that the functions $\phi_{1}, \phi_{2}, \phi_{3}$ change in the region where $N_{2}\left[\Pi_{\mathrm{M}}-\Pi_{\mathrm{M}}^{\mathrm{E}}(t)\right]<G$.
} 


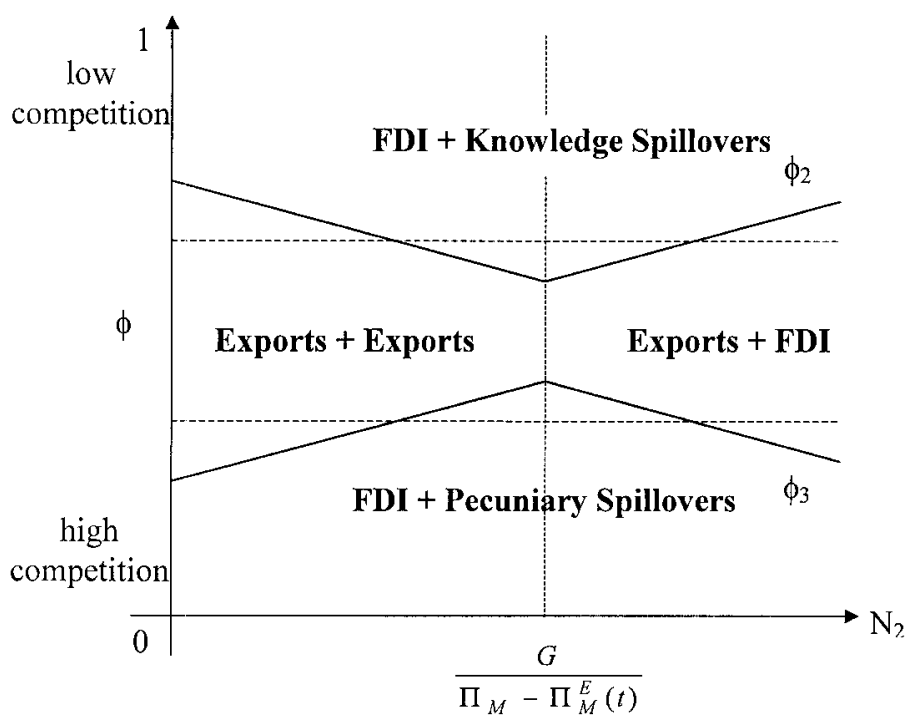

Fig. 4. Non-monotonicities in $N_{2}$.

\subsection{Different contractual arrangements}

So far we have assumed that the worker is wealth and credit constrained and only one-period contracts can be written. The two assumptions are crucial for our results, and exports would never occur if either of them were relaxed.

If contracts are complete, there exist several contractual arrangements that allow the MNE to enjoy all the rents accruing to its superior technology. One such arrangement is a two-period employment contract with the worker. A two-period contract rules out the possible mobility of the trained worker in the second period, and the trained worker is hired at the subsistence wage $(w=0)$. This contract trivially eliminates all technological and pecuniary spillovers.

However, when the sum of the duopoly profit (net of $k$ ) is higher than the monopoly profits the aggregate rents are maximized when the worker leaves for the local firm It is therefore optimal to include a clause in the contract sketched above that specifie a penalty that has to be paid by the worker if the contract is broken. By setting the penalty equal to $\operatorname{Max}\left\{\left(\Pi_{\mathrm{D}}(\phi)-k\right),\left(\Pi_{\mathrm{M}}-\Pi_{\mathrm{D}}(\phi)\right)\right\}$, technological spillovers happen precisely when they maximize the aggregate rents. Furthermore, the penalty allows the MNE to extract all rents in the industry. Under the assumptions made, FDI is always the first-perio internationalization strategy and the existence of technological spillovers is driven by inequality (1). 
If the trained worker is not wealth constrained (for instance, because she can ask for a bank loan), the MNE anticipates her second-period extra wage and therefore asks for a negative first-perio wage [either $w=-\left(\Pi_{\mathrm{D}}(\phi)-k\right)$ if she will stay at the subsidiary or $w=-\left(\Pi_{\mathrm{M}}-\Pi_{\mathrm{D}}(\phi)\right)$ if she will move to a local firm] This ensures that the aggregate rents are maximized and that all rents are captured by the MNE.

\section{Summary and conclusions}

Spillovers have often been treated as a "black box" mechanism, where their nature is left unspecified This paper provides a specifi mechanism through which technology might involuntarily move from a fir towards others located in the same country. Therefore, the paper offers a rationale to the empirical literature which has uncovered the importance of localized spillovers (e.g., Audretsch and Feldman, 1996).

We have presented a model where technological spillovers from FDI might occur due to workers' mobility. A MNE can transfer a superior technology to its foreign affiliat only after having trained a local worker. Once trained, this worker can later be hired by a local fir and technological spillovers might occur. Even when such spillovers do not take place, the host country's welfare might improve because of the wage that the trained worker receives from the MNE to prevent her from moving to a local firm

We have also shown that, in some circumstances, the MNE might prefer to export rather than to invest, precisely to avoid diffusion of superior technology to the local rival and/or the payment of rents to the trained worker.

Our model helps to identify the conditions under which a MNE retains the trained worker, and those under which she leaves to a local firm The results are consistent with the industrial organization literature on persistence of monopolies. Technological spillovers arise (the monopoly ceases to exist) when the "jointprofit' effect does not hold, that is, when industry profit are higher if both firm can use the technology. This is more likely to happen when the local fir and the MNE do not compete fiercel in the product market (or sell in independent or vertically related markets), when on-the-job training is general rather than specific and when the absorptive capability of the local fir is high. We have accordingly identifie some empirical predictions to which our model gives rise.

\section{Acknowledgements}

We are grateful to G. Bertola, B. Cassiman, A. Ciccone, T. Cordella, M. Ebell, M. Ganslandt, J. Markusen, P. Regibeau, A. Soro Bonmatí , F. Zilibotti, a 
co-editor, two anonymous referees, and participants at seminars at the University of Colorado (Boulder), World Bank (Washington, DC), Aix-en-Provence, Lausanne, CEPR (London), Bologna (ASSET Meeting) and EUI (Florence) for comments on a previous draft. Partial financia support from the Spanish Ministry of Education through DGYCIT grant PB94-0663 (Motta) is also gratefully acknowledged. The usual disclaimers apply. This paper was written when all three authors were at Universitat Pompeu Fabra.

\section{References}

Acemoglu, D., Pischke, J.S., 1998. Why do firm train? Theory and evidence. Quarterly Journal of Economics 113, 79-119.

Aitken, B., Harrison, A., Lipsey, R.E., 1997. Wages and foreign ownership: a comparative study of Mexico, Venezuela, and the United States. Journal of International Economics 43, 103-132.

Audretsch, D.B., Feldman, M.P., 1996. R\&D spillovers and the geography of innovation and production. American Economic Review 86 (3), 630-640.

Becker, G., 1964. Human Capital. Columbia University Press, New York.

Behrman, J., Wallender, H., 1976. Transfer of Manufacturing Technology within Multinational Enterprises. Ballinger, Cambridge, MA.

Blömstrom, M., 1986. Foreign investment and productive efficiency the case of Mexico. Journal of Industrial Economics 15, 97-110.

Blömstrom, M., Kokko, A., 1998. Multinational corporations and spillovers. Journal of Economic Surveys 12 (3), 247-278.

Borensztein, E., De Gregorio, J., Lee, J.W., 1998. How does foreign direct investment affect economic growth? Journal of International Economics 45, 115-135.

Budd, C., Harris, C., Vickers, J., 1993. A model of the evolution of duopoly: does the asymmetry between firm tend to increase or decrease? Review of Economic Studies 60 (3), 543-574.

Budden, M.C., 1996. Protecting Trade Secrets Under the Uniform Trade Secrets Act. Quorum Books, Westport, CT.

Chen, E.K.Y., 1983. Multinational Corporations, Technology and Employment. Macmillan, London.

Cohen, W., Levinthal, D., 1989. Innovation and learning: the two faces of R\&D. Economic Journal 99, 569-596.

d'Aspremont, C., Jacquemin, A., 1988. Cooperative and noncooperative R\&D in duopoly with spillovers. American Economic Review 78 (5), 1133-1137.

Ethier, W.J., Markusen, J.R., 1996. Multinational firms technology diffusion and trade. Journal of International Economics 41, 1-28.

Fosfuri, A., Motta, M., 1999. Multinationals without advantages. Scandinavian Journal of Economics $101(4), 617-630$.

Fosfuri, A., Motta, M., Rønde, T., 1998. Foreign direct investments and spillovers through workers' mobility. Universitat Pompeu Fabra, Working Paper No. 248, available on the Internet at http: //www.econ.upf.es/cgi-bin/allpapers.

Gerschenberg, I., 1987. The training and spread of managerial know-how. A comparative analysis of multinationals and other firm in Kenya. World Development 15, 931-939.

Horstmann, I.J., Markusen, J.R., 1992. Endogenous market structure in international trade (natura facit saltum). Journal of International Economics 32, 109-129.

Horstmann, I.J., Markusen, J.R., 1996. Exploring new markets: direct investment, contractual relations and the multinational enterprise. International Economic Review 37 (1), 1-19. 
International Labour Organization, 1981. Multinationals' Training Practices and Development. ILO, Geneva.

Kokko, A., 1994. Technology, market characteristics, and spillovers. Journal of Development Economics 43, 279-293.

Kudo, A., 1993. I.G. Farben in Japan: the transfer of technology and managerial skills. Business History, 159-183.

Lall, S., 1980. Vertical interfir linkages in LDCs: an empirical study. Oxford Bulletin of Economics and Statistics 42, 203-226.

Lee, J.Y., Mansfield E., 1996. Intellectual property protection and U.S. foreign direct investment. Review of Economics and Statistics 78 (2), 1-9.

Lindsey, C.W., 1986. Transfer of technology to the ASEAN region by U.S. transnational corporations. ASEAN Economic Bulletin 3, 225-247.

Mansfield E., Romeo, A., 1980. Technology transfer to overseas subsidiary by U.S.-based firms Quarterly Journal of Economics 95, 737-750.

Motta, M., 1992. Multinational firm and the tariff-jumping argument. European Economic Review 36, 1557-1571.

Pack, H., 1993. Exports and externalities: the sources of Taiwanese Growth. Mimeo.

Rodriguez-Clare, A., 1996. Multinationals, linkages, and economic development. American Economic Review 86 (4), 851-873.

Siotis, G., 1999. Foreign direct investment strategies and firms capabilities. Journal of Economics and Management Strategy 8, 251-270.

Tirole, J., 1988. The Theory of Industrial Organization. MIT Press, Cambridge, MA.

UNLTC, 1993. In: Enderwick, P. (Ed.), Transnational Corporations and Human Resources, Vol. 16. United Nations, Routledge. 